12th LUMEN International Scientific Conference Rethinking Social Action. Core Values in Practice | RSACVP 2019 | 15-17 May 2019 | lasi - Romania

\title{
The Impacts of Perceived Ethical Climate and Codes of Ethics on Employees' Deviant Behaviors in Organizations
}

\author{
Cosmin VECHIU, Liliana BUDEVICI - PUIU \\ https://doi.org/10.18662/lumproc. 178
}

How to cite: Vechiu, C., \& Budevici - Puiu, L. (2019). The Impacts of Perceived Ethical Climate and Codes of Ethics on Employees' Deviant Behaviors in Organizations. In C. Ignatescu (ed.), 12th LUMEN International Scientific Conference Rethinking Social Action. Core Values in Practice, 15-17 May 2019, Iasi - Romania (pp. 308-340). Iasi, Romania: LUMEN Proceedings. https://doi.org/10.18662/lumproc.178 


\title{
The Organization of Cognitive Activity and Teaching Based on the Scientific Investigation Model
}

\author{
Cosmin VECHIU1 ${ }^{1}$, Liliana BUDEVICI - PUIU²
}

\begin{abstract}
The issue of scientific investigation gains a special significance in an ever-changing economic, social and political environment where almost all aspects of education, and in particular education, starting with funding, content, quality, efficiency of educational systems and activities, are brought into question. According to the literature and models of good educational practices, there is important evidence of scientific research that highlights that teaching subjects by approaching the scientific investigation method, contribute to fostering of school pupils / students motivation, educating their scientific spirit and intellectual development. In this context, teachers have a significant role to play in applying specific techniques of scientific knowledge in the act of teaching, i.e. to teach school pupils / students how knowledge, idea and science are produced, because only so its values will truly be assimilated. Moreover, in order to facilitate the implementation of investigation-based learning and teaching models in authorized / accredited study programs within educational institutions, it is essential to promote the educational vision of teachers and, most importantly, in the specific activities of educational institution.
\end{abstract}

Keywords: teaching, scientific investigation, model of learning, theoretical subjects, knowledge, cognitive activities

\section{Introduction}

The knowledge activity made by teachers within and out of the higher education institution occupies the bulk of all the activities planned for their preparation and improvement. Education without cognitive activities is virtually impossible to conceive, as a low-level education of students is ineffective, especially when we seek to shape them for a contemporary,

\footnotetext{
${ }^{1} \mathrm{PhD}$, Doctoral School ,The State University of Physical Education and Sports, Chisinau, Republic of Moldova, vechiu_cosmin@yahoo.com,+40740478830

$2 \mathrm{PhD}$,associate professor, The State University of Physical Education and Sports, Chisinau,Republic of Moldova, lilianapuiu27@gmail.com, +37368114146.
} 
modern and continually changing society characterized by complexity and mobility [1,2]. Moreover, the degree of understanding and awareness of students in the education process is usually of significant importance in their formation, development and transformation, since of this level of knowledge generally depends on the interest and scientific curiosity, attitudes and abilities to act in different situations corresponding to the field in which they specialize[1,2].

Analyzing the specifics of traditional education, we can discover some essential characteristics reflected by:

- the primary objective of the training is represented by acquisition as many knowledge as possible;

- the knowledge is mostly carried out indirectly, respectively between the students and the reality of studying, several intermediaries interpose themselves (the teacher, the university courses, the books, the notes, etc.);

- teaching and learning are often reduced to the transmission and reception of information;

- the predominant intellectual activity of students is memorable, repetitive and reproductive;

- student thinking and actions are focused and directed from the outside;

- the teacher-student relationship is asymmetric, respectively it can be done an influence only from teacher to student and not vice versa (the student cannot influence the act of teaching or learning, because learning involves compliance, but compliance involves passive dependence).

In this context, we can mention that the traditional education focuses on the cognitive aspects of the student, constantly monitoring his / her gradual preparation, on study subjects, so that through this is ignored the harmonization of the cognitive aspect of the person with attitudinal and behavioral [3].

\section{Problem Statement}

The aim of the study is to elaborate and apply the model of scientific investigation in organizing cognitive activity and teaching of theoretical subjects from authorized and accredited study programs within faculties of physical education and sport. Thus, the model will be used in an interactive context, which will generate a modern alternative for the reconceptualization of teaching - learning of the theoretical subjects provided in the study plans of these programs.

According to the literature, the investigation is a set of educational practices that promote question-based learning and the identification of 
concrete solutions to them through research. Finding answers and solutions involves "a variety of processes and ways of thinking that support the development of new scientific knowledge" [4].

\section{Research Questions/Aims of the research}

Regarding the question "Do you use in the teaching the method of scientific investigation?" We can see from the answers recorded and reflected in Figure 1 that most of the teachers partly use the scientific investigation in the teaching of theoretical subjects.

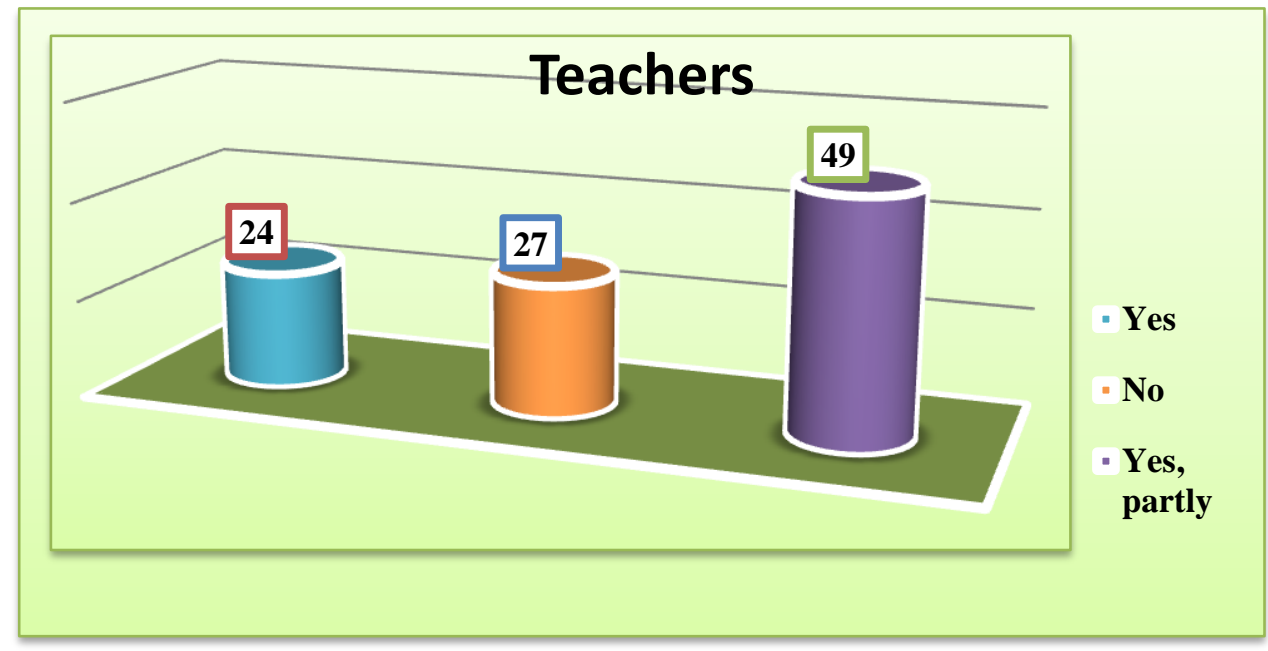

Figure 1. Replies on the use of the method of scientific investigation in teaching

Regarding the answers to the question, "Which of the benefits of using the scientific investigation in teaching can provide students with a more effective learning process?" From the Figure 2 results that by addressing teaching based on scientific research / investigation in theoretical disciplines, can provide for students more effective learning process whereas they develop their observation spirit (watch carefully, take notes, compare and find out some facts and theoretical studies ) - $21 \%$; proceed in dialogue and constructive communication between the teacher and the students (ask questions about the observations made to support the investigation, written, oral or by proxy information are transmitted) - 25\%; investigative and interpreting activities are carried out (planning, measurements, data collection, variables control, synthesis, drafting conclusions and models) $28 \%$; active participation of students in the process of learning through 
demonstration, collaboration, involvement in scientific research studies, exchange of innovative ideas and risk assumption - $26 \%$.

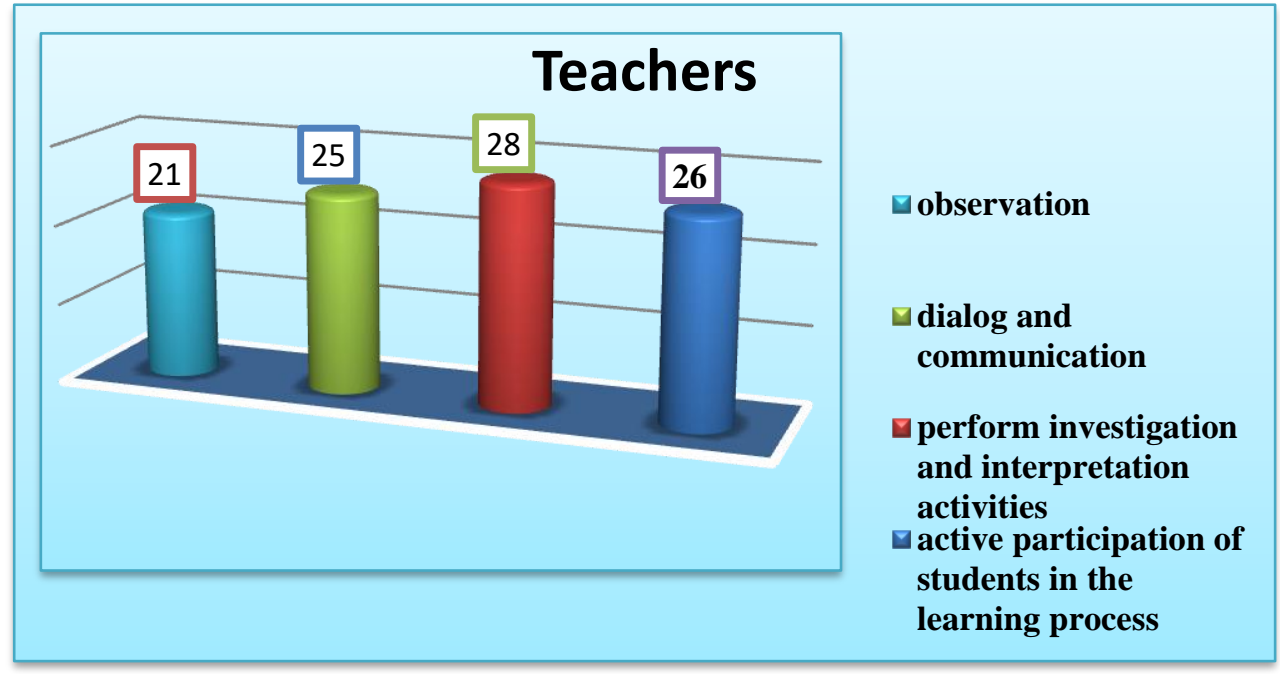

Figure 2. Replies on the benefits of using the scientific investigation in teaching

In the current stage of development of higher education, knowledge should be modeled by using methods and technologies from the field of scientific investigation, in order to educate the scientific spirit of students, arm them with innovative research methodologies, to develop them the intellectually and morally. If to date, higher education institutions have dealt more with the processing of scientific products, it is now very important to take over the technique of scientific knowledge, i.e. to teach students how knowledge, idea, science is produced, because only so its values will be truly assimilated. In this context, we asked the teachers "Do you think it is important to have information about the dynamics of the students' knowledge process in the disciplines you teach?", and through the replies made an affirmative share of over $70 \%$ is observed. 


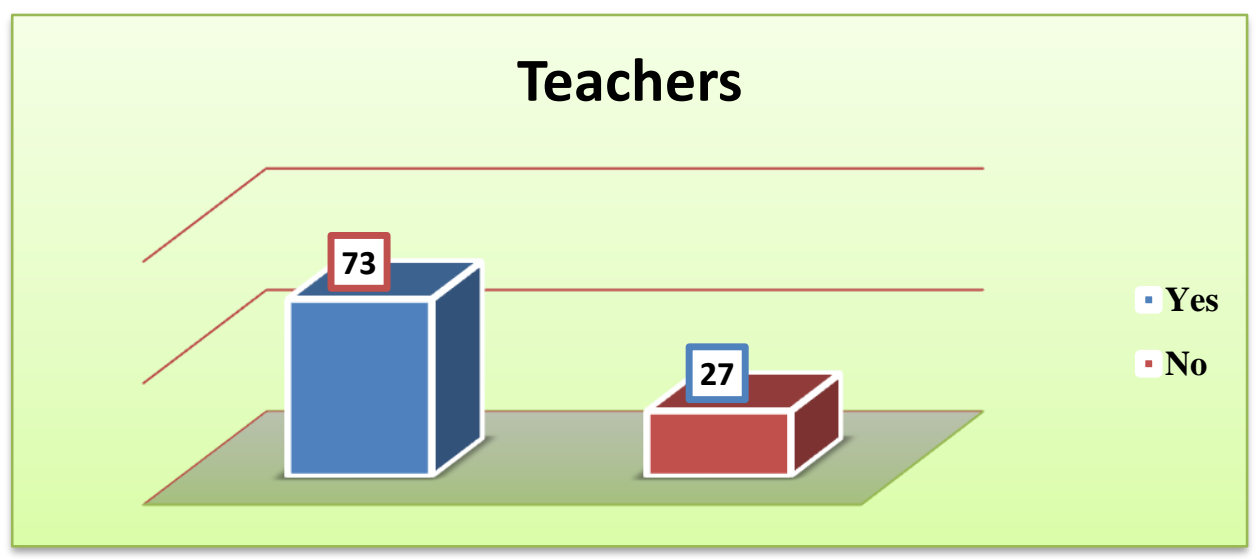

Figure 3. Replies regarding the possession of information about the dynamics of student knowledge process

Regarding the question "Can you mention some concretely identified situations by approaching the scientific investigation in the teaching of the theoretical subjects?" It can be seen from Figure 4 that by approaching this method in teaching can occur situations such as: a less direct involvement of the teachers in the act of teaching and a larger one in modeling, guiding, facilitating and continuously evaluating students' results - $16 \%$; the role of the teacher becomes more complex in terms of capacities for understanding of concepts taught to students - 18\%; increase the responsibility of the teacher in developing student ideas and for maintaining the learning environment - $21 \%$; developing skills in teachers to stimulate and provide the necessary support for students in the process of learning scientific ideas $23 \%$; the teachers involved in the process of teaching to a greater extent the role of facilitator of the law of education, respectively, to encourage investigation, observation and thinking, stimulating students' attention, comments, experimentation of new things and situations, fact what will generate them the training and development of research skills, innovation and competitive spirit - $22 \%$. 


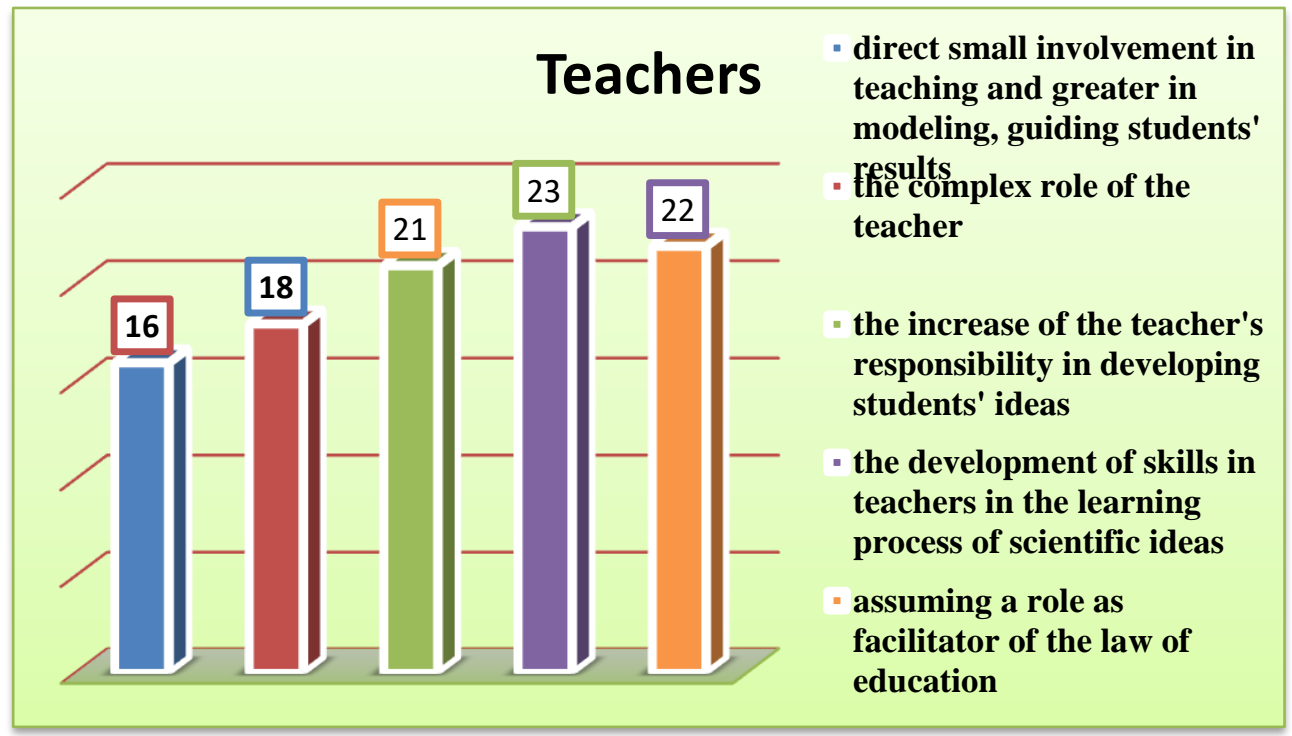

Figure 4. Replies to concrete situations identified by approaching scientific investigation in teaching of theoretical subjects

Regarding the replies to the question "Do you think that the model of teaching and learning through investigation can contribute to the formation of the key competences of the specialist in the field?" We can see that affirmative values were recorded in over $80 \%$ - Figure 5 .

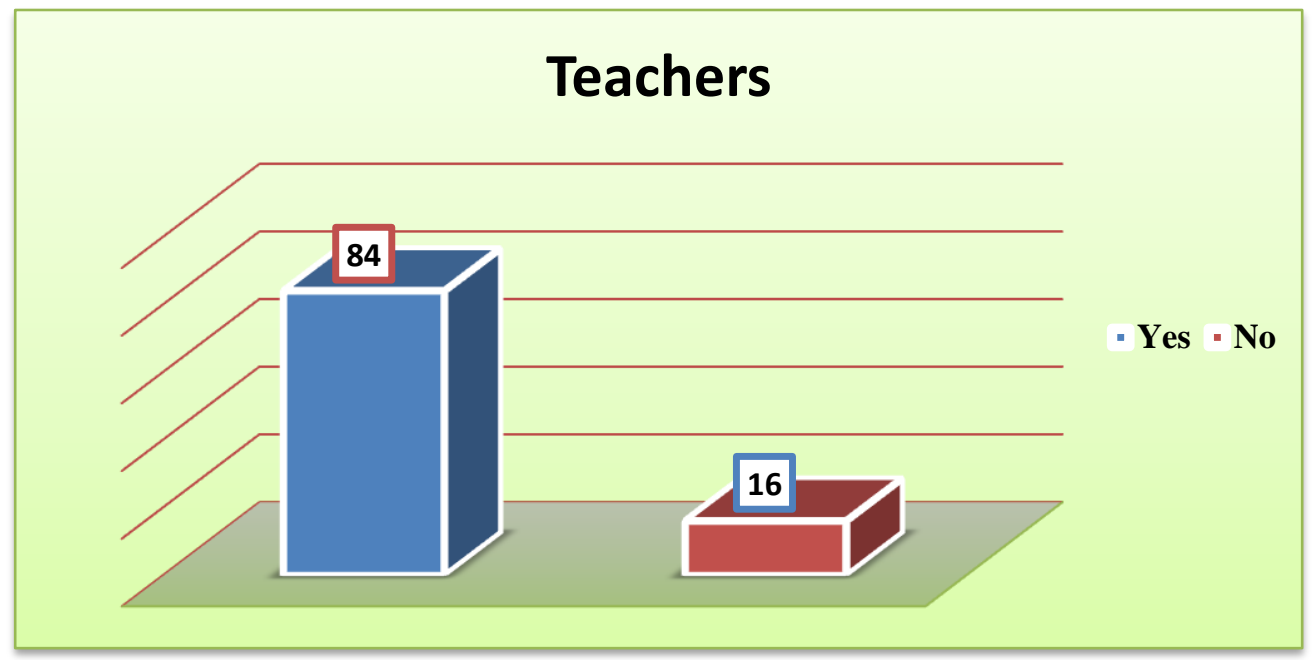

Figure 5. Replies on the teaching and learning model through investigation versus key competencies 


\section{Research Methods}

Methodology of research: literature analysis, learning method based on research / investigation; observation, the sociological questionnaire (its content was formulated according to the purpose of the research and the objectives set, the structure and the content of the questionnaire followed a logical scheme, containing both general and specific questions.) Before applying to the categories of respondents, the questionnaire was validated through an instrumental type research (pilot survey) carried out on a number of 128 people) and pedagogical monitoring.

In order to elaborate the scientific investigation model necessary to be applied in the organization of cognitive activity and the teaching of the theoretical subjects from the profile faculties, we monitored some practical problems approached by the specialized teachers which ensure the teaching of the theoretical subjects (selected from the study plans for the realization of the research purpose ) with reference in particular to: university curricula, teaching-learning-evaluation relationship, teaching strategies and styles, concrete models for determining the effectiveness and efficiency of teaching, evaluation of the didactic creative behavior of the teacher, the dynamics of the knowledge process, the modality and objectives of the research / scientific investigation applied in the act of teaching selected disciplines.

\section{Findings}

In Table 1 we highlight the actions of the teacher for organizing cognitive activity and assuring the teaching of selected theoretical subjects from the curricula of the Master's program, the specialization "Physical Culture Management" within the faculty of Pedagogy of the State University of Physical Education and Sport, Chisinau.

Table 1. The actions of the teacher for organizing cognitive activity and assuring the teaching theoretical subjects

\begin{tabular}{|l|l|l|}
\hline \multicolumn{1}{|c|}{ Actions } & \multicolumn{1}{|c|}{$\begin{array}{c}\text { Organization of } \\
\text { cognitive activity }\end{array}$} & \multicolumn{1}{c|}{$\begin{array}{c}\text { Teaching theoretical } \\
\text { subjects }\end{array}$} \\
\hline $\begin{array}{l}\text { Introducing a } \\
\text { curriculum centered } \\
\text { on competence } \\
\text { training at the } \\
\text { discipline of study }\end{array}$ & $\begin{array}{l}\text { Switching to a } \\
\text { paradigm of a } \\
\text { functional educational } \\
\text { culture }\end{array}$ & $\begin{array}{l}\text { Learning units in } \\
\text { theoretical subjects } \\
\text { should become active by } \\
\text { associating with the } \\
\text { learning model specific to } \\
\text { the scientific } \\
\text { investigation }\end{array}$ \\
\hline Use of competency & Inclusion of some & Approach in the process \\
\hline
\end{tabular}




\begin{tabular}{|c|c|c|}
\hline $\begin{array}{l}\text { learning models } \\
\text { (learning through } \\
\text { research projects, } \\
\text { problem solving, } \\
\text { experiments-based } \\
\text { learning) }\end{array}$ & $\begin{array}{l}\text { research activities in } \\
\text { order to develop the } \\
\text { innovative approach to } \\
\text { students and focus on a } \\
\text { proactive learning } \\
\text { strategy }\end{array}$ & $\begin{array}{l}\text { of teaching models: } \\
\text { problem solving and } \\
\text { model of systematic } \\
\text { observation }\end{array}$ \\
\hline $\begin{array}{l}\text { Asking some open } \\
\text { questions which have } \\
\text { as their object } \\
\text { explanation of some } \\
\text { concepts and } \\
\text { phenomena }\end{array}$ & $\begin{array}{l}\text { Students' knowledge, } \\
\text { skills and abilities will } \\
\text { be formed and } \\
\text { developed with the } \\
\text { investigation of replies } \\
\text { to these questions }\end{array}$ & $\begin{array}{l}\text { By addressing } \\
\text { investigation in teaching, } \\
\text { it is ensured explanation } \\
\text { of concepts and } \\
\text { phenomena based on } \\
\text { open questions, while } \\
\text { advancing hypotheses } \\
\text { and reflecting on the } \\
\text { evidence accumulated }\end{array}$ \\
\hline $\begin{array}{l}\text { Ensuring of some } \\
\text { learning contents that } \\
\text { will stimulate } \\
\text { students critical } \\
\text { thinking }\end{array}$ & $\begin{array}{l}\text { Cognitive tasks should } \\
\text { ensure that non- } \\
\text { standard issues are } \\
\text { solved }\end{array}$ & $\begin{array}{l}\text { Teaching takes account } \\
\text { of mutation and needs of } \\
\text { employers, and teachers } \\
\text { have more and more } \\
\text { feedback }\end{array}$ \\
\hline $\begin{array}{l}\text { Changing the way of } \\
\text { valuing knowledge } \\
\text { and skills of the } \\
\text { students }\end{array}$ & $\begin{array}{l}\text { Building of some } \\
\text { formative assessment } \\
\text { tools that will allow the } \\
\text { stimulation and } \\
\text { development of } \\
\text { cognitive processes }\end{array}$ & $\begin{array}{l}\text { The formative } \\
\text { assessment will } \\
\text { essentially contribute to } \\
\text { providing the students } \\
\text { with the necessary } \\
\text { support in teaching } \\
\text { process, giving them the } \\
\text { opportunity to figure out } \\
\text { how to learn and } \\
\text { understand the process of } \\
\text { acquiring knowledge }\end{array}$ \\
\hline
\end{tabular}

In Figure 6, we reflect the model of scientific investigation established and implemented in organizing cognitive activity and teaching theoretical subjects from approved and accredited study programs within faculties of physical education and sport [3]. 


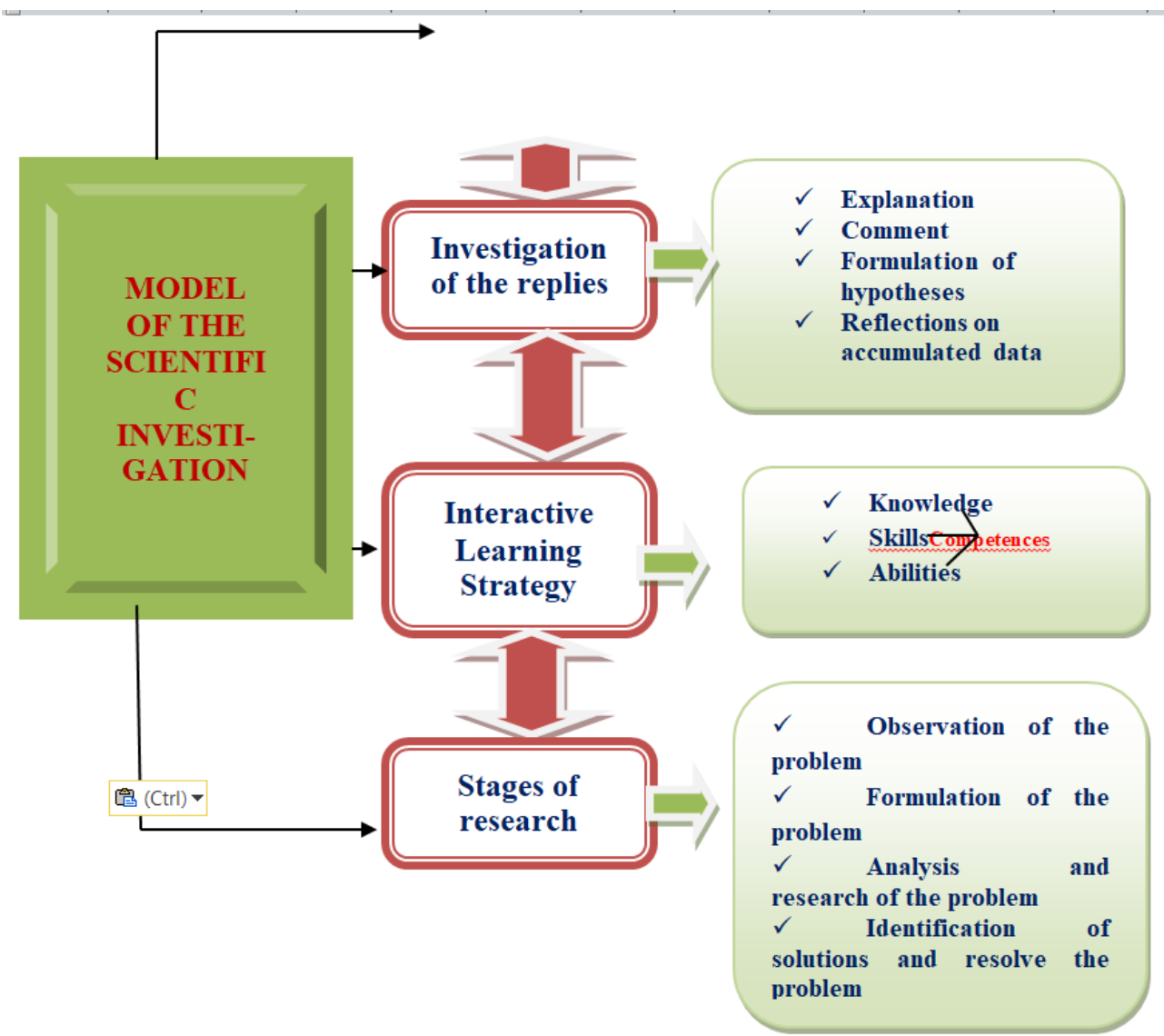

Figure 6. The model of scientific investigation established and implemented in the organization of cognitive activity and the teaching theoretical subjects

\section{Conclusions}

The scientific investigation model has significant advantages in terms of requesting cognitive activity and student creativity, but we must keep in mind that creative behavior is not limited to mere investigative action, the creative act is to be finalized by reducing to synthesizers schemes, concrete models learning, better linked and more structured. Such a model can generate innovation in the process of teaching - learning students through investigational, practical activities, by "manipulating" objects, images or concepts. Moreover, they will carry out activities to discover the new reality and identify new ways of organizing logical learning structures, namely acquisition of acquired knowledge and, last but not least, skills training. 
By the proposed model, we consider that there is a structural change in the concept of teaching - learning of the theoretical subjects selected in the study, with consequences of the highest importance for the elaboration of the stages of the educational process and for the building of some innovative didactic methodologies. Thus, scientific investigation, as a fundamental form of knowledge and research, is no longer avoided, nor is it assigned a small role, simply consolidating knowledge, but it is restored to rights as the main way of acquiring knowledge, training skills, personality development, suitability of the study to the needs of the employer. Also, learning becomes more enjoyable, more exhilarating and more thorough when students base their ideas and thoughts on their own constructive activities, investigative activity, and applications that precede explanations.

\section{References}

[1] Bogner FX., Schmid S, Dieser O. Predarea ştiințelor prin investigație, Ghid pentru profesori în cadrul Proiectului Pathway 266624. 2013;p. 72.

[2] Bybee, R. W. (2000). Teaching science as inquiry. In van Zee, E. H. (Ed.), Inquiring into Inquiry Learning and Teaching Science (pp. 20-46). Washington, DC: AAAS.

[3] Manolachi V, Budevici-Puiu L. The Insurrance and Evaluation of the Scientific Research Qualitty within the Instituttion of Higher Education of Physical Training and Sport from Republic of Moldova: Journal of Management Systems, QUAL ITY 65 Access to success, Scopus, 17(150)// February 2016.

[4] Flick U. An Introduction to Qualitative Research. London:Sage Publications; 2006 